\title{
魚肉ねり製品の原料魚の漁獲に投入される直接执よび 間接エネルギーの推定
}

\author{
渡辺尚㢁・内田純一
}

(1983 年 6 月 15 日受理)

\begin{abstract}
An Estimation of Direct and Indirect Energy Input in Catching Fish for Fish Paste Products
\end{abstract}

\section{Hisahiko WATANABE*1 and Jun-Ichi UCHIDA*1}

\begin{abstract}
There has been no publication on the energy analysis of catching fish for fish paste products. This paper reports an estimation of direct and indirect energy input per kilogram of catch of these fishes, by use of the census of fisheries economics. It was found that the energy input per weight of catch in the fishing of Alaska pollack (distant trawl in North Pacific Ocean) was nearly constant at the level of about $5,000 \mathrm{kcal} / \mathrm{kg}$ from 1967 to 1977 . But it increased greatly in the year of 1978. It reached $20,000 \mathrm{kcal} / \mathrm{kg}$ in 1980 . On the other hand, the energy intensity in the fishing of croaker and others (trawl in East China Sea) has been gradually increasing year by year. It was $8,000 \mathrm{kcal} / \mathrm{kg}$ in 1967 and $18,000 \mathrm{kcal} / \mathrm{kg}$ in 1980 . It was also found that $80-90 \%$ of the total energy was consumed as fuel oil by fishing boat in both cases.
\end{abstract}

産業連関表を用いたエネルギ一分析”によると水産食 品部門はその製品 $1 \mathrm{~kg}$ に対する 1 次エネルギー投入量

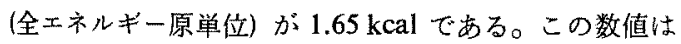
肉製品部門の $0.65 \mathrm{kcal} / \mathrm{kg}$ や酪農品部門の $0.31 \mathrm{kcal} / \mathrm{kg}$ と比べて大さい。本研究は，このようにェネルギー投入 量が大きいとされる水産食品の中でる, 加工度が高くか つ生産量の大きい魚肉㓡り品について，原料魚の漁獲 加ら最終製品の製造に至るまての各過程においてエネル ギーがどのよ5に投入されるかを明らかにし，今後の対 策に資すことを目的とする。魚肉权り製品製造の諸過程 を Fig. 1 に示す。スケトウダラ冷凍すり身製造の過程

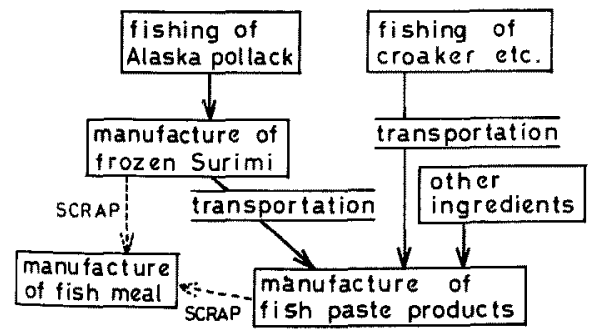

Fig. 1. The flow chart of the manufacture of fish paste products.
に拈ける投入エネルギーの分析については既に報告し た。 本稿では原料魚の漁獲過程での投入エネルギーに ついて検討与る。

魚肉权り製品には極めて多種類の製品があり，また， その原料には 100 種類以上の魚種が利用されている。 しかしながら，量的に大半を占めるのはスケトウダラ と, グチ・ニベ・タチウオ等以西底びき網漁業の漁獲物 と考光られる。本研究では，原料魚の㴔獲を代表するる のとして北洋の遠洋底びき絧漁業（北転船）と以西底び き網漁業をとり上げる。

\section{推 定方 法}

スケトゥダラ漁業の代表例として，北洋に乩ける200500 トン規模の漁船による遠洋底びき網漁業(北転船) を、李た、グチ・ニべタチりオ等については、真シナ

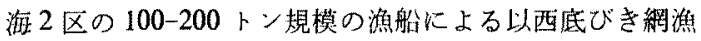
㧘を選ぶ。これらの漁業の1湩缷体あたりの平均的な漁

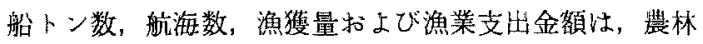

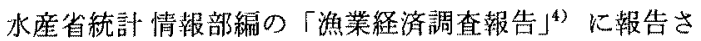
れている。*2 (Table 1 参照) スケトウダラ漁業の場合 は, 平均して, 347 トンの海船1隻に上るオッタート口 一ルで炤和 49 年に 13 回出漁し，6,089トンの漁獲が

*1 東京水應大学食品工学科 (Department of Food Technology and Engineering, Tokyo University of Fisheries, Kohnan-4, Minato, Tokyo 108, Japan)

*2 閒接エネルギーを推定する時に，エネルギー濃度 (エネルギ一集中度) 必要とするが，本研究では，昭和 49 的

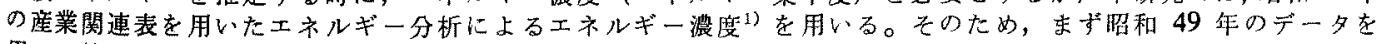
用いて检討する。年次による変動について法後節にて検討する。 
Table 1. The average cost expended by a fisheries operating unit with an average scale in distant trawl in North Pacific Ocean and that in trawl in East China Sea in 1974

\begin{tabular}{|c|c|c|c|c|c|}
\hline \multicolumn{2}{|l|}{ Items } & \multicolumn{2}{|c|}{$\begin{array}{l}\text { Distant trawl in } \\
\text { North Pacific Ocean } \\
\text { (北 転 船) }\end{array}$} & \multicolumn{2}{|c|}{$\begin{array}{c}\text { Trawl in } \\
\text { East China Sea } \\
\text { (以西底びき網漁業) }\end{array}$} \\
\hline \multicolumn{6}{|l|}{ Fishing boat } \\
\hline Tonnage of main boat & & \multicolumn{2}{|c|}{347.44} & \multicolumn{2}{|c|}{117.77} \\
\hline Number of powered boat & & \multicolumn{2}{|c|}{1} & \multicolumn{2}{|c|}{2} \\
\hline Number of voyage & & \multicolumn{2}{|c|}{13} & \multicolumn{2}{|r|}{5} \\
\hline Landings of catch [tonnes] & & \multicolumn{2}{|c|}{6088.9} & \multicolumn{2}{|c|}{1020.8} \\
\hline$\left[10^{3}\right.$ yen $]$ & & \multicolumn{2}{|c|}{270,454} & \multicolumn{2}{|c|}{209,348} \\
\hline Total cost & （漁業支出合計） & $\begin{array}{c}\text { Cost } \\
{\left[10^{3} \text { yen }\right]} \\
245,917\end{array}$ & $\begin{array}{c}\text { (per cent) } \\
(100.0)\end{array}$ & $\begin{array}{c}\text { Cost } \\
{\left[10^{3} \text { yen }\right]} \\
212,878\end{array}$ & $\begin{array}{r}\text { (per cent) } \\
(100.0)\end{array}$ \\
\hline Crew-share & （踓 用 学 黍） & 78,328 & $(31.9)$ & 71,015 & $(33.3)$ \\
\hline Boat repair and maintenance & (漁 船 費) & 18,837 & $(7.7)$ & 20,053 & $(9.4)$ \\
\hline Fishing gear repair & (瀂 具 费) & 20,594 & $(8.4)$ & 8,833 & $(4.1)$ \\
\hline Fuel oil & 代) & 53,307 & $(21.6)$ & 24,630 & $(11.6)$ \\
\hline Bait & $(\dot{z}$ & - & $(-)$ & - & $(-)$ \\
\hline Ice & (水 & 937 & $(0.3)$ & 2,408 & $(1.2)$ \\
\hline Casings of catch & （魚箱 代） & 1,861 & $(0.8)$ & 13,220 & $(6.2)$ \\
\hline Miscellaneous coat & （諸 材 料 費） & 1,357 & $(0.5)$ & 1,518 & $(0.7)$ \\
\hline Facilities repair and maintenance & (諸 施 設 蒜) & 1,423 & $(0.5)$ & - & $(-)$ \\
\hline Lent fee & （貨借料 - 料 金) & 1,245 & $(0.5)$ & 20,069 & $(9.4)$ \\
\hline Sales commission fee & (販 売 手 数 料) & 11,001 & $(4.5)$ & 11,010 & $(5.2)$ \\
\hline Management cost & （事務 費） & 11,581 & $(4.7)$ & 13,670 & $(6.4)$ \\
\hline Other running cost & (その他 経 常費) & 3,925 & $(1.6)$ & 11,729 & $(5.5)$ \\
\hline Depreciation & （減 做 償 却費） & 41,522 & $(16.8)$ & 14,723 & $(6.9)$ \\
\hline Buildings & (建 物) & 361 & $(0.1)$ & 227 & $(0.1)$ \\
\hline Boat & 船) & 33,838 & $(13.7)$ & 11,131 & $(5.2)$ \\
\hline Fishing gear & (漁網・はえなお) & 6,614 & $(2.6)$ & 216 & $(0.1)$ \\
\hline Fishery right & （㴡業権） & - & $(-)$ & 2,773 & $(1.3)$ \\
\hline Other fixed assets & （その他固産資産） & 708 & $(0.3)$ & 377 & $(0.2)$ \\
\hline
\end{tabular}

あり 2 檍 4,592 万円の漁業支出を要している。他方, グ チ・ニペ・タチウオ等を対象魚種とする以西底びき緬漁 㘹では 118 トンの漁船による二隻底びき網で 5 回の航海 を行ない1,022トンの漁獲を得たが，この潐業の為に2 境 1,288 万円の潐業支出を要した。本研究ではこれらの 経済的な情報を利用して投入エネルギーの推定を行な 50

な拈，北洋での底びき網漁業（北転船）での漁獲魚種 は約 $90 \%$ がスケトウダラでその他にヒラィ・カレイ類 が $6.8 \%$ 程度混獲される。占た，以西底びき網での漁

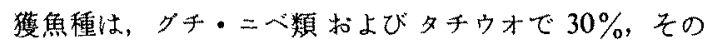
他に，八モ・エン・エイ・ホウボウの類が $15 \%$ 程度漁

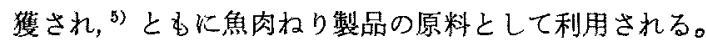
従って，以西底びき稀に上る漁獾物の䄪 $1 / 2$ がかり製品 の原料となる。以西底びき網漁業のその他の漁獲魚種

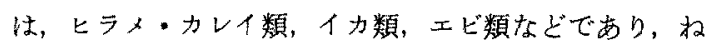
り製品原料魚に劣ら双市場価値を有している。そこで、
本研究ではこれらの非衩り製品原料魚もねり製品原料 魚と対等の価值を有すると考え，全エネルギーが全漁獲 物心同等に投入されたとして計算を行なら。

\section{敵接投入エネルギー}

漁獲に際しての直接投入エネルギーは漁船の燃料油お よび事務で使う電力拉よびガソリン・灯油等である。 Table 1 の経常経實の項目に事務費があるが，これ柱 に人件費であり, ${ }^{\text {) }} こ の$ 経費から事務用の直接エネルギ 一に対応するものを推定するのは困難なので，本稿では 潐船の然料油以外はすべて間接ェネルギーとして报ら。 また，Table 1 中の油代は然料油費の他に潤滑油費をも 含もが，雨者を区別するのが困嚾なので聞滑油費を無视 してすべて然料費として报ら。然料油性とんど全部A 重油とみなせる。䀡和 49 年のA重油平均単洒を $29 \times$ $10^{3}$ 円 $/ \mathrm{k} l$ とし, ${ }^{8)} \mathrm{A}$ 重油の全エホルギー原単位を 10,913 $\mathrm{kcal} / l$ としで然料㴼のエネルギーを算出した。 


\section{間接投入エネルギー}

間接投入ェネルギーは特記するるのを除いて，一般 に，投入金額にェネルギー濃度を乗じて算出した。ただ し，エネルギー濃度は資源調查会資料第 69 号に揭戴さ れている值りを用いた。

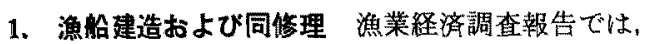
漁船の建造炕関する費目が減価償却費に，漁船の修理や 消耗品代関する費目が漁船費にはいらている。同報告の 他の漁法・漁場火関する報告を㐼世見ると，漁船の減洒 償却費は必ずしも漁船の総トン数の大小を反映せず不合 理な部访がある。これは，减価償却には会計上の都合に よる任意操作の加かる余地があるためと考えられる。そ こでTable 1 の漁船の減価償却費は採用世ず，刮途に漁 船の建造船価を推定し，それを耐用年数で除して1年あ たりの漁船建造費とした。漁船の建造船価を推定する試 みとして，昭和 45 年，49 年，55 年について，建造船 伍》を総トン数に対して雨対数プロットしたところ，各 年次ともとれぞれ勾配がほぼ1の直楾で相関できること がわかった。 (Fig. 2 参照) 本研究ではこの図を用いて 漁船の建造船価を推定した。

一般火漁船の减価償却の法定年数は，鋼船 12 年，木 船 7 年, FRP 船 10 年である。些際は法定償却前に他国

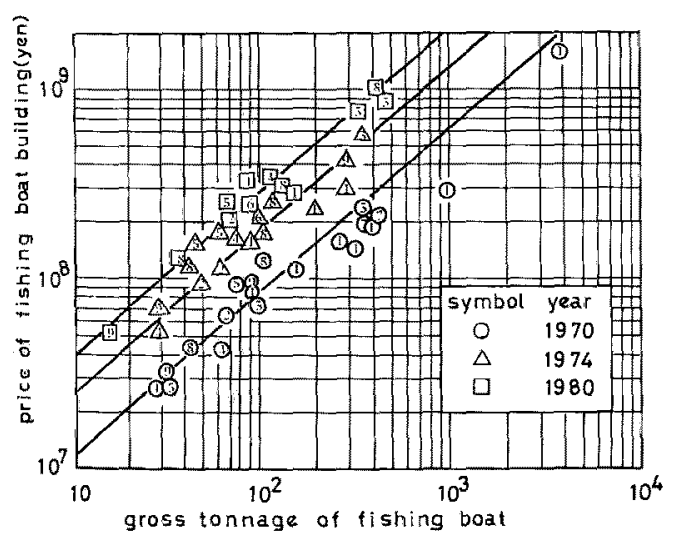

Fig. 2. The relation of the price vs. the gross tonnage in fish boat building. The figure in the symbol denotes each fishery as follows:

1: distant water tuna long line; skipjack pole-and-line,

2: offshore tuna long line; skipjack pole-andline,

3: distant trawl 4: offshore trawl

5: offshore salmon drift gill net

6: factory ship type salmon fishing

7: North Pacific Ocean long line and gill net

8: purse seines 9: others
へ伀売される例も多いらしいがこここでは上記の值を参 考にして，漁船の耐用年数を 10 年と仮定した。このよ ろにして得た漁船建造費に，造船・同修理部門のエネル ギ一嘼度 ${ }^{1)}(15.91 \mathrm{kcal} / 円)$ を乘じて投入エネルギーを算 出した。なお，漁船修理については，Table 1 の漁船費

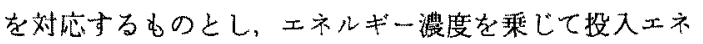
ルギーとした。

2. 漁具製造むよび同修理 遠洋底びき網漁業（北転 船）仕平均して 347 トンの漁船に上って行なかれ，1隻

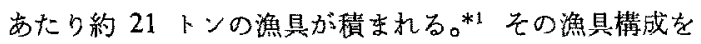
打拈よそ,ナイロンロープ類 $(66.8 \%)$ ，ナイロン網地 $(4.2 \%)$ ，オッター・ボード $(29 \%)$ と推定した。(カッ コ内は重量パーヒント*3) 漁具の耐用年数を 3 年とし た。また、ロープ扰よび絧地のエネルギ一原単位として ナイロンのエネルギー原単位 ${ }^{12}\left(33.9 \times 10^{3} \mathrm{kcal} / \mathrm{kg}\right)$ を、 またオッター・ボードについては，熱間圧趠鋼材の ネルギ一原単位 ${ }^{1)}\left(5.17 \times 10^{3} \mathrm{kcal} / \mathrm{kg}\right)$ を用いた。Table 1 に漁具費として計上されているすのは漁具消耗費・修 纉費である。この漁具費に「ロープ・漁網」部門のエネ ルギー濃度を乗して漁具修理の投入ェネルギーとした。

以西底びき絧漁業に出漁する各々 118 トンの漁船は 2 隻で 12.4 トンの漁具を積んでいると推定し，その漁具 はナイロンロープおよびナイロン網地により棈成されて いるとみなした。漁具の耐用年数を3年と仮定した。漁 具修理の投入エネルギーについては，北転船の場合と同 様に計算した。

3. 砕水製造 漁船用の碎水を製造する製水工場で年 間 $3.73 \times 10^{5}$ トンの水を生産するのに $3.46 \times 10^{8} \mathrm{kWh}$ の 電力消䚉を要したとされている。影電力を 1 次エネルギ - $(1 \mathrm{kWh}=2,000 \mathrm{kcal}$ と与る。 $)$ 変換すると砕水 1 卜 ンあたりのエネルギー投入量は $1.86 \times 10^{4}(\mathrm{kcal} / \mathrm{t})$ とな

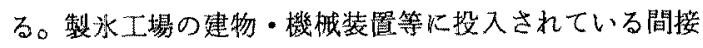
的なエネルギー投入量を直接投入エネルギー（電力）の $1 / 2$ と仅定吉る ${ }^{11}$ と，碎水 1 トソに投入される全ェネル

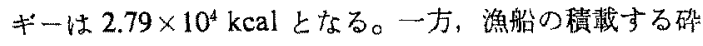
水の量を漁船要覧 ${ }^{12)}$ にっって推定すると, 1 航海あたり, 北洋の遠洋底びき絧漁羑で 15.0 トン, 以西底びさ網漁業 で67.2トンKなる。これらの值を用いて，漁獲量 $1 \mathrm{~kg}$ あたり碎氷製造に投入されたェネルギーを推定した。

4. 魚箱代 Table 1 で見る通り，以西底びき䋚漁業 では魚箱代への支出が油代の 1/2 という巨額に達してい る。以西底びき絧漁業による权り製品原料魚は大部分木 箱に入れられるので,「木製品」部門のェネルギー浱度” (11.2 kcal/円) を用いてェネルギーに換算した。

5. 諸材料 諸材料費の項目は, 漁具を除く一般作業

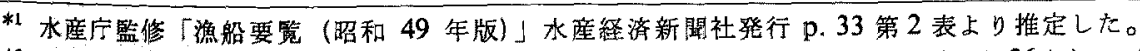

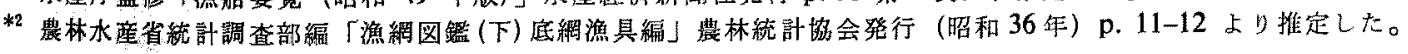


用の用品・雑货類であると考え，ゴ製品で代表させて 投入メネルギーを算出した。

6. 建物・諸施設 建物の減価償却殞捛上び経常経殞 の諸施設貿の合計金類に、「非住宅新建築」部門のエネ ルギー濃度 ${ }^{1}(22.85 \mathrm{kcal} / /$ 问）を渠じて建物・諸施設への 投入ェネルギーとした。

7. 告借料・料金について 以西底びき絧㴡業の珼偕 料・料金は他と比較して異常に大きい。また，経常経䩀 の㴔船費（修理・蟻装の材料費・部品資）が大きいにも

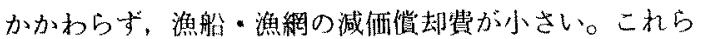
のことから，Table 1 に示した以西底びき網㴔業では潐 船 1 隻が貨倩に上り速用されているものと考えられる。 このことからも，投入ェネルギーの推定に減洒償却費を 利用することは道切でないといえる。

8. 事雅についてこの項目は, 役員給与・手当, 事務職員給与一手当, 接待費, 出張費，事務用品費を含 むもので, ${ }^{8)}$ 大部分が人件費と推定される。従って, 間 接投入エネルギーから除外した。

9. 労华・手数料等について 本米, 労働やサービス に関与る投入エネルギーも検討の対象となるべきので 西るが，取り扱いちに難点を有するので本研究では除外 した。

\section{結果と考察}

昭利 49 年に打けるスケトウダラ漁業（北転船）打よ び以西底びき網漁業における平均的 1 漁撚体あたりの直 接怙よび間接投入エネルギー（全投入エネルギー）拈よ び漁獲 $1 \mathrm{~kg}$ あたりの全投入エネルギーの推筧結果を Table 2 に示した。同表より，1漁管体あたりの年間の エネルギー投入量はスケトウダラ湶業の力が以西底びき

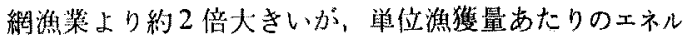
ギ一投入量（エネルギー原単位）は以西底びき網漁業の 万が約 3 偣大きいことがわかる。これはスケトウダラ㴔 莱の方が 1 漁䈍体あたりの湶隻量が約 6 倍多いからであ る。

産業連関分析の手法を用いたエネルギー分析では，昭 利 49 年の日本の海面潐業部門のエネルギ一原単位は $9.3 \times 10^{3} \mathrm{kcal} / \mathrm{kg}$ である。 ${ }^{1}$ 立た，イギリスに括ける同粎 な分析 ${ }^{13)}$ では, 1969 年のイギりスの漁業部門のエネル ギ一原単位は $34.6 \mathrm{MJ} / \mathrm{kg}\left(8.0 \times 10^{3} \mathrm{kcal} / \mathrm{kg}\right)$ であり, 日 本の値と活活一致している。このような産業連関分析K

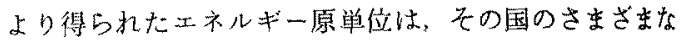

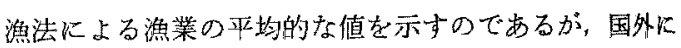
拈计る然料油の䝼入を傿視しているので, 遠洋漁業の占 める割合の大きい国では，実際はより大きな数值になる と思わ机る。

Table 2 K示したスケトウダラ漁業のエネルギー原単 位は $3.3 \times 10^{3} \mathrm{kcal} / \mathrm{kg}$ であり, 産業連関分析による值の $1 / 3$ 之少なく，また，以西底びき網漁業の原単位は 10.6 $\times 10^{3} \mathrm{kcal} / \mathrm{kg}$ で虐業連関分析による值とは结一致する。 一般厄，漁船の然料使用量の公表されたデータは乏しい が，最近，省エネルギー研究を目的として，まぐる漁船 の然料油の使用状況が詳しく調査された。和)とれによる と, 潐獲量 $1 \mathrm{~kg}$ 西たりの重油使用量は昭和 55 年 炤和 56 年に打いて，2.0 8.01であり，エネルギー換算する と $2 \times 10^{4} \sim 9 \times 10^{4} \mathrm{kcal} / \mathrm{kg}$ となる。これは, 本研究に よる以西底びき網漁業の 2 9 倍である。漁場の遠近，

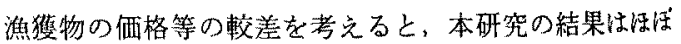
納得でさる数值を与えているものと考えられる。

投入エネルギーの頊目別内訳をみると，然料油がスケ

Table 2. The average energy input of a fisheries operating unit in distant trawl in North Pacific Ocean and that in trawl in East China Sea in 1974

\begin{tabular}{|c|c|c|c|c|}
\hline \multirow{2}{*}{ Items } & \multicolumn{2}{|c|}{$\begin{array}{l}\text { Total energy input per } \\
\text { fisheries operating unit } \\
{\left[10^{\mathrm{B}} \mathrm{kcal}\right]}\end{array}$} & \multicolumn{2}{|c|}{$\begin{array}{l}\text { Total energy input per } \\
\text { kilogram weight of catch } \\
{[\mathrm{kcal} / \mathrm{kg}]}\end{array}$} \\
\hline & $\begin{array}{l}\text { Distant trwal } \\
\text { in North } \\
\text { Pacific Ocean }\end{array}$ & $\begin{array}{c}\text { Trwal in } \\
\text { East China } \\
\text { Sea }\end{array}$ & $\begin{array}{l}\text { Distant trwal } \\
\text { in North } \\
\text { Pacific Ocean }\end{array}$ & $\begin{array}{l}\text { Trwal in } \\
\text { East China } \\
\text { Sea }\end{array}$ \\
\hline Direct energy input & & & $(\%)$ & $(\%)$ \\
\hline Fuel oil & 18,179 & 8,340 & $2,986(90.1)$ & $8,820(85.8)$ \\
\hline \multicolumn{5}{|l|}{ Indirect energy input } \\
\hline Boat building and repair & 1,070 & 871 & $176(5.3)$ & $852(8.3)$ \\
\hline Fishing gear manufacture & & & & \\
\hline and repair & 818 & 413 & $135(4.1)$ & $404(4.0)$ \\
\hline Ice manufacture & 5 & 9 & $1(0.0)$ & $9(0.1)$ \\
\hline Casing of catch & 21 & 148 & $3(0.1)$ & $145(1.4)$ \\
\hline Miscellaneous & 44 & 49 & $7(0.2)$ & $48(0.5)$ \\
\hline Building and facilities & 41 & 5 & $7(0.2)$ & $5(0.0)$ \\
\hline Total & 20,178 & 9,835 & $3,315(100)$ & $10,283(100)$ \\
\hline
\end{tabular}


トゥダラ漁業で約 $90 \%$ ，以西底びき秱漁業で約 $80 \%$ と、いずれにおいても压倒的な比率を占めている。従っ て, 省エネルギーの方途は, 漁船計器や漁具・漁法の高度 化，適切な漁船運用等による然料油消沸の軽減にあると 言交よう。しかしながら，支出金額に占める比率において は, Table I 亿示す通り，然料油の比深は全体の 10-20\% にすぎず，ェネルギー投入量における比率とは全く異な っている。従って, 経営上の判断としては, 必ずしも然 料油の節减が第 1 の重要事項にならないことがかかる。

さて，以上の检討は，いずれる，昭和 49 年のデータ に限定されたるので苛った。しかるに，近年，エネルギ 一価格の暴騰，200海里経斎圈の設定などの要因に上り， 漁業は大きな影響を受けている。そこで，昭和 42 年 (1967 年) から昭和55 年(1980年) 末での14年間に わたる資料4)を用いて投入エネルギーの経年変化を検討 した。ェネルギーへの換算にあたって，昭和 49 年の座 業連関表を用いて得られたェネルギー浱度を用いた。そ のため，まず各年次の諸資材価格を昭和 49 年の佂格に 換算し, 次いで昭和 49 年のエネルギー濃度を乗じた。 $\mathrm{A}$ 重油の価格变動は全漁連加盟の漁協の扱い単価変動を 用いて補正した。 ${ }^{8,18)}$ その他の漁業資材の価格変動は， 卸売物価指数 ${ }^{16)}$ を用いて補正した。海業経済調查報告に 記載された北洋遠洋底びき網漁業（北転船）战よび以西 底びき網漁業の各年の平均的 1 漁撘体あたりの全圷ル ギー投入量, 㴔蒦 $1 \mathrm{~kg}$ あたりの全エネルギー投入量の 推算結果をそれぞれ Fig. 3 および Fig. 4 亿示した。ま た，各年の平均的 1 漁㩐体あたりの漁獲量の変化党Fig. 5 に示した。これらの結果をみると、スケトウダラ漁業 (北転船) と以西底びき絧漁業とはバターンが全く巽なる ことがわかる。以西底びき網漁業では 14 年間漁獲量が 汪济一定である。しかし投入エネルギーは漸增して来 た。そのため，単位漁獲量あたりのエネルギ一投入量は 昭和 42 年 (1967 年) 頃に $1 \times 10^{4} \mathrm{kcal} / \mathrm{kg}$ 程度であっ たが、その後, 年々增加し, 昭和 55 年 (1980 年) には

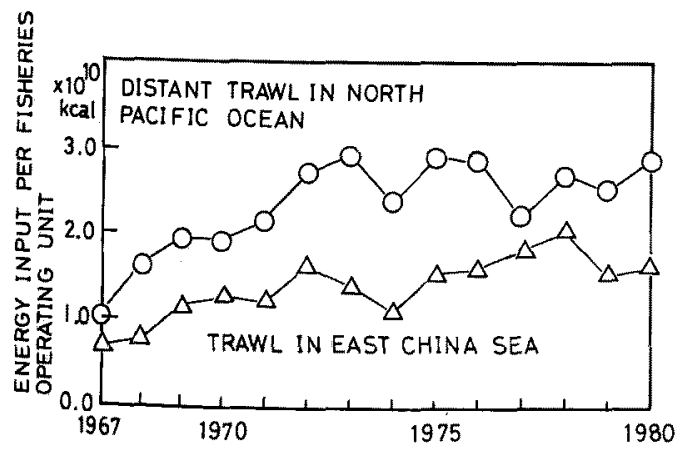

Fig. 3. The trend of total energy input per fisheries operating unit.

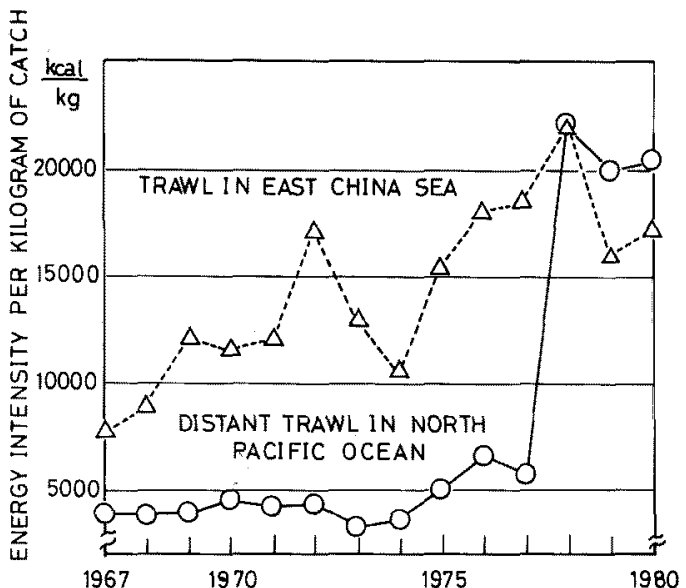

Fig. 4. The trend of energy intensity per kilogram of catch from 1967 to 1980.

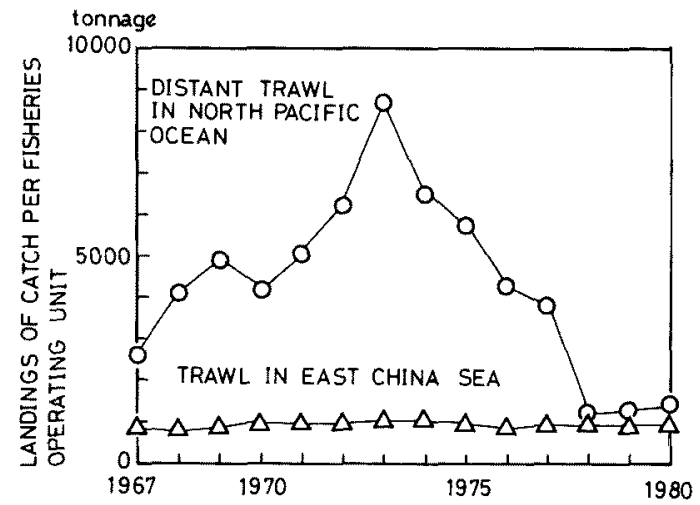

Fig. 5. The trend of landings of catch per fisheries operating unit from 1967 to 1980.

約 $2 \times 10^{4} \mathrm{kcal} / \mathrm{kg}$ となった。他方，スケトウダラ漁業で は，投入ェネルギーが年々，以西戍びき網漁業を上廻る 速さで增大していたが，それに伴って漁獲量も增大した ため，単位漁獲量あたりのェネルギー投入量は昭和 42

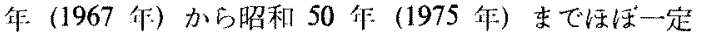
$\left(4 \times 10^{3} \sim 5 \times 10^{3} \mathrm{kcal} / \mathrm{kg}\right)$ であった。しかし，漁獲量が 昭和 48 年（1973 年）をピークに和々減少したにもかか わらず投入エネルギーが減少しなかったため，単位漁獲 量あたりのエネルギ一投入量が増加しはじめ, 特に昭和 53 年 (1978 年) には従来の5 倍程度にまで急増し, 以 西底びき網漁業より多くなった。この急增時期は，ソ連 やアメリカの 200 海里漁業水域の設定時期と一致してい る。

全国統計をみると，この時期のスタトウダラ冷湅すり 身の生産量は年間汪添 30 万トンで特に減少はして扰ら ず, ${ }^{10)}$ すり身の生産歩留を $25 \%$ と仮定すると, 冷涷す り身仕向のスケトウダラ消費量を 120 万トン程度と推定 


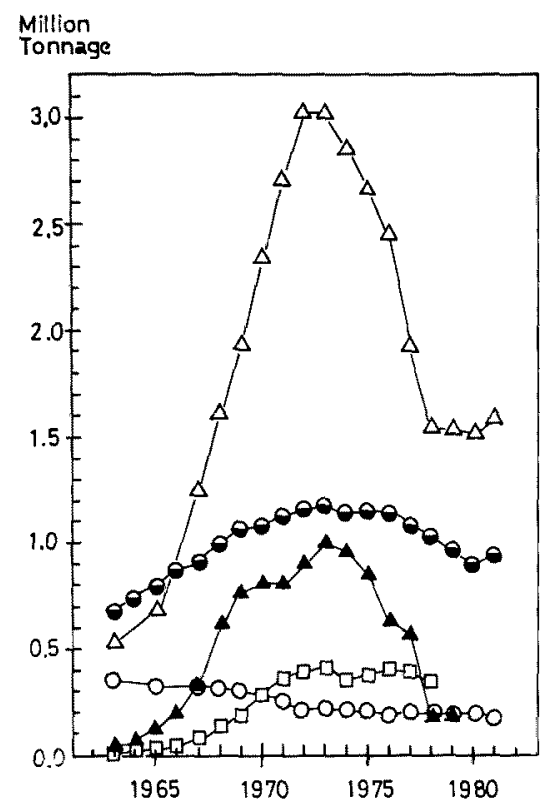

Fig. 6. The trend of catch of fish and production of fish meat paste. ${ }^{18)}$ The symbols denote as follows:

$\triangle:$ total catch of Alaska pollack

$\Delta$ : catch of Alaska pollack by distant trawl in North Pacific Ocean (hokutensen)

[] : total production of frozen surimi of Alaska pollack

0 : catch by trawl in East China Sea

$\ominus$ : total production of finished goods of fish meat paste

できる(Fig. 6 参照)。全国のスケトウダラ生産量が结ぼ 150 万トンであるから，以前には，フィッシュミール用 にも大量に消費されていたスケトウダラがこの時期以降 は大部分が冷集すり身用となったことがわかる。また，

Fig. 6 に示すよらに，スケトウダラの全生産量に占める 北転船の生産量が昭和 53 年以降は激減している。促っ て，スタトウダラの漁獲に関して馀ずるためには，是非 と夕，母船式底びき網や北方トロールによるスケトウダ ラの漁獲に関するデータが必要上なるが，データは公表 されていない。単純化して言えば，Fig. 4 亿示された北 転船漁業の昭和 52 年(1977 年) をでの低いエネルギー 原単位は土に, 従来のフィッシュミール用のスタトウダ 亏漁業に対尤し，昭和 53 年(1978 年) 以降の高いエネ ルギー原単位が，現在の炩凍寸り身用のスケトウダラ漁

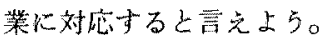

$$
\text { 要約 }
$$

漁業経済調查報告に示された経済的情報捄よび，廒業 連関表を用いたエネルギー分析の情報を用いて，魚肉水
り製品の代麦的な原料魚であるスケトウダラ和よびタ テ・ニべ・タチウ才等の漁獲過程に投入される直接和よ び間撄エネルギーの推定を行ない，単位漁獲量あたりの 全エネルギ一投入量（エネルギー原単位）を算出した。 北転船によるスケトウダラ漁獲のエネルギー原単位は昭 和 42 年 (1967 年) から昭和 52 年 (1977 年) まて怡 4,00-6,000 kcal/kg であったが，昭和 53 年 (1978 年) 以降急增し, 昭和 55 年 (1980 年) には $20,000 \mathrm{kcal} / \mathrm{kg}$ に達している。他方，グキ・ニベ・タチウオ等を漁獲す る以西底びき絧漁寀のエネルギー原単位は、昭和 42 年 (1967 年) に $8,000 \mathrm{kcal} / \mathrm{kg}$ 程度であったが，その後㴬 增し，昭和 55 年 (1980 年) には $18,000 \mathrm{kcal} / \mathrm{kg}$ にな っている。また，投入ェネルギーの項目别内訳では，い 少れの場合も然料油が 80-90\%とい5压倒的比率を占め ている。

本研究の逐行にあたり有益なご助䆑を賜った東京水産 大学の竹内正一 - 高井陸雃 - 加瀬和俊 - 大海原宏の各氏 に深謝する。本研究の経費の一部は昭和 57 年度文部省 科学研究貿補助金（エネルギ一特別研究）によった。

\section{文献}

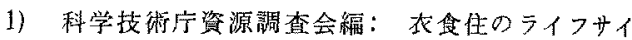
クルエネルギー (資料第 69 号)，大藏省印刷局， 東京, 1979 年, pp. 60-365.

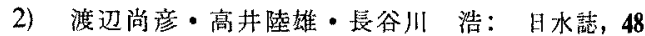
(7), 941-944 (1982).

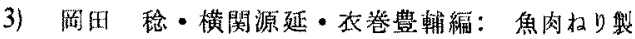
品, 恒星社厚生闒, 1974, pp. 169-170.

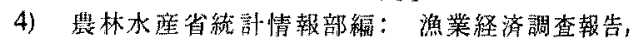
(企業体の部)，農林統計協会，昭和 42 年版 (1969 年) 昭和 55 年版 (1982 年)。

5)茛林水産省統計情報部編：漁業楸殖業生産統計

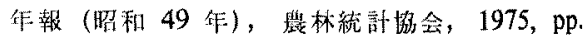
21-23.

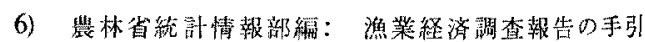
(企業体の部)，農林統計協会，1970, pp. 31-32.

7) 水座年鑑 (昭和 51 年版)，水産社，東京，1976， p. 354.

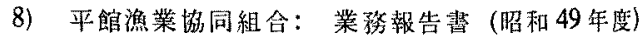
p. 14.

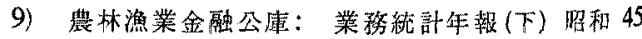
年版 (1971)，昭和 49 年版 (1975)，炤和55年版 (1981)

10)冷凍空調技術, 33, 23 (1982).

11) Y. TANAKa and T. Udagawa: Energy Analyses of Agriculture Fisheries and Forestry, Miscellaneous Publication of the National Institute of Agricultural Sciences No. 25 (1981) p. 77.

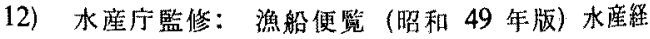
済新聞社, p. 33 .

13) G. Leach: Energy and Food Production, IPC Science and Technology Press (1976) p. 125. 
14）渙船協会：かつ括まぐろ漁船の省エネルギ対策 p. 131 (1981).

15) 日本銀行統計局：経済統計年報 (昭和 56 年) p. 289 .

16)水座庁監修: 水産凟料総覽(昭和 56 年版) 地 球社, 東京, 1980 . 